\title{
Nonstarter Lactic Acid Bacteria and Aging Temperature Affect Calcium Lactate Crystallization in Cheddar Cheese
}

\author{
Y.-E. Chou, C. G. Edwards, L. O. Luedecke, M. P. Bates, and S. Clark \\ Department of Food Science and Human Nutrition, \\ Washington State University, Pullman, WA 99164-6376
}

\begin{abstract}
The occurrence of unappetizing calcium lactate crystals in Cheddar cheese is a challenge and expense to manufacturers, and this research was designed to understand their origin. It was hypothesized that nonstarter lactic acid bacteria (NSLAB) affect calcium lactate crystallization (CLC) by producing $\mathrm{D}(-)$-lactate. This study was designed to understand the effect of NSLAB growth and aging temperature on CLC. Cheeses were made from milk inoculated with Lactococcus lactis starter culture, with or without Lactobacillus curvatus or L. helveticus WSU19 adjunct cultures. Cheeses were aged at 4 or $13^{\circ} \mathrm{C}$ for $28 \mathrm{~d}$, then half of the cheeses from 4 and $13^{\circ} \mathrm{C}$ were transferred to 13 and $4^{\circ} \mathrm{C}$, respectively, for the remainder of aging. The form of lactate in cheeses without adjunct culture or with L. helveticus WSU19 was predominantly $\mathrm{L}(+)$-lactate $(>95 \%, \mathrm{wt} / \mathrm{wt})$, and crystals were not observed within 70 d. While initial lactate in cheeses containing L. curvatus was only $\mathrm{L}(+)$-lactate, the concentration of $\mathrm{D}(-)$-lactate increased during aging. After $28 \mathrm{~d}$, a racemic mixture of $\mathrm{D} / \mathrm{L}$-lactate was measured in cheeses containing $L$. curvatus; at the same time, CLC was observed. The earliest and most extensive CLC occurred on cheeses aged at $13^{\circ} \mathrm{C}$ for $28 \mathrm{~d}$ then transferred to $4^{\circ} \mathrm{C}$. These results showed that production of $\mathrm{D}(-)$-lactate by NSLAB, and aging temperature affect CLC in maturing Cheddar cheese.
\end{abstract}

(Key words: nonstarter lactic acid bacteria, aging temperature, calcium lactate crystallization, Cheddar cheese)

Abbreviation key: $\mathbf{C L C}=$ calcium lactate crystallization, $\mathbf{D} \%=$ percentage of $\mathrm{D}(-)$-lactate in total lactate in cheese (wt/wt), NSLAB = nonstarter lactic acid bacteria, treatment $4^{\circ} \mathrm{C}=$ aged at $4^{\circ} \mathrm{C}$, treatment $4^{\circ} \mathrm{C}-$ $13^{\circ} \mathrm{C}=$ aged at $4^{\circ} \mathrm{C}$ for $28 \mathrm{~d}$ then transferred to $13^{\circ} \mathrm{C}$, treatment $13^{\circ} \mathrm{C}-4^{\circ} \mathrm{C}=$ aged at $13^{\circ} \mathrm{C}$ for $28 \mathrm{~d}$ then transferred to $4^{\circ} \mathrm{C}$, treatment $13{ }^{\circ} \mathrm{C}=$ aged at $13^{\circ} \mathrm{C}$.

Received September 4, 2002.

Accepted February 14, 2003.

Corresponding author: S. Clark; e-mail: stephclark@wsu.edu.

\section{INTRODUCTION}

According to the International Dairy Foods Association (2001), US Cheddar cheese production in 2000 was approximately $1.4 \times 10^{6}$ tons, an amount that represents $35 \%$ of all cheese varieties manufactured. Although Americans have access to many quality Cheddar cheeses, defects such as white crystals are detrimental to the appearance quality of Cheddar cheese and reduce sales. The appearance of crystals on cheese has been particularly disturbing to consumers since the fall of 2001 with heightened awareness of anthrax and bioterrorism (personal communication with processors in the United States, 2001 to present).

Even though the occurrence of undesirable crystals in Cheddar cheese has been documented since the 1930s (McDowall and McDowell, 1939), the problem still represents a challenge and expense to cheese manufacturers today (personal communication with processors in the United States, 1998 to present). The crystals have been most frequently identified as calcium lactate (Severn et al., 1986; Dybing et al., 1988; Johnson et al., 1990a; Johnson et al., 1990b). The development of calcium lactate crystals may result from a number of causes, including differences in milk composition (Pearce et al., 1973), cheesemaking procedure (Dybing et al., 1988), aging temperature (Pearce et al., 1973; Dybing et al., 1988; Johnson et al., 1990b), and the growth of nonstarter lactic acid bacteria (NSLAB) in cheese during aging (Johnson et al., 1990b; Somers et al., 2001).

NSLAB may enter the cheesemaking process at any point before packaging (Thomas et al., 1985; Khalid and Marth, 1990; Somers et al., 2001). While starter bacteria are typically homofermentative Lactococcus spp. and produce predominantly $\mathrm{L}(+)$-lactate from lactose, NSLAB in Cheddar cheese may be homofermentative (Lactobacillus plantarum, Lactobacillus casei, Lactobacillus curvatus, Pediococcus spp.) or heterofermentative (Lactobacillus brevis, Lactobacillus fermentum, or others) (Turner and Thomas, 1980; Thomas and Crow, 1983; Khalid and Marth, 1990; Somers et al., 2001). Although starter bacteria make up the majority of cheese microflora initially, NSLAB dominate the 
viable population in cheese for much of the ripening period (Khalid and Marth, 1990; Williams et al. 2000). Hydrolytic enzymes produced by NSLAB induce proteolysis and lipolysis during cheese maturation, leading to flavor production, affecting cheese quality (Khalid and Marth, 1990; Shakeel-Ur-Rehman, et al. 2000).

Heterofermentative NSLAB utilize a variety of substrates for growth and produce an assortment of metabolites, including both $\mathrm{L}(+)$ - and $\mathrm{D}(-)$-lactate (Dybing et al., 1988; Williams et al., 2000). NSLAB that are capable of racemizing $\mathrm{L}(+)$-lactate to $\mathrm{D}(-)$-lactate can contribute to calcium lactate crystallization (CLC) since D(-)lactate is less soluble than L(+)-lactate, particularly at cold temperatures, in maturing cheese (Johnson et al., 1990b). In the early 1990s, Johnson et al. (1990b) established correlations among CLC, lactic acid enantiomer, and numbers of NSLAB. Cheeses with and without racemase-positive Lactobacillus were packaged into 9-kg blocks, and incubated at 7.2 and $10^{\circ} \mathrm{C}$. After $5 \mathrm{wk}$, cheeses were unwrapped, cut into $0.45-\mathrm{kg}$ pieces, repackaged, then placed at the original temperature or at $3.3^{\circ} \mathrm{C}$ for 4 wk. Cheeses with racemase-positive Lactobacillus, stored at $3.3^{\circ} \mathrm{C}$ after cutting, developed crystals to a greater extent than the same cheeses stored at 7.2 or $10^{\circ} \mathrm{C}$ after cutting. Cheeses without lactobacilli added did not undergo CLC. CLC was never observed on cheeses with less than $20 \%$ of the lactic acid in the $\mathrm{D}(-)$ form. It follows, then, that since high temperatures favor the growth of NSLAB (Turner and Thomas, 1980; Shakeel-Ur-Rehman et al., 2000), aging cheese at high temperatures, as may be done to accelerate ripening, can result in elevated $\mathrm{D}(-)$-lactate by NSLAB and induction of CLC (Johnson et al., 1990b). Additionally, aging of cheese at low temperatures may also increase CLC, due to decreased solubility of calcium lactate at a low temperature (Linke, 1958).

In addition to the above explanations for CLC, a common practice that may lead to CLC, but has not received literature review, is the procedure of "cut and wrap". Frequently, large blocks of cheese are sold to vendors, who cut and wrap smaller pieces, slices, or shreds of natural Cheddar cheese for retail sale. The cut and wrap process may introduce secondary NSLAB contamination. Secondary NSLAB introduced at the cheese plant (Somers et al., 2001) or during cut and wrap may proliferate upon stimulation by warm tempering temperatures, and NSLAB capable of racemizing $\mathrm{L}(+)$ - to D(-)-lactate may induce CLC (Blake, 2000).

In the present study, initial milk lactose concentration, protein/fat ratio, and starter bacteria and NSLAB lactobacilli innocula were controlled. The study was designed to examine the involvement of specific lactobacilli NSLAB on CLC and the effects of aging temperature on NSLAB growth, lactose and lactate metabolism, and subsequent CLC in maturing Cheddar cheese made with standardized cheese-milk.

\section{MATERIALS AND METHODS}

\section{Sources of NSLAB}

Two strains of Lactobacillus curvatus, \#1 and \#11, were isolated from mature Cheddar cheeses exhibiting crystals, obtained commercially in Washington state, and identified according to Rengipat and Johnson (1989) and Zúñiga et al. (1993). L. helveticus WSU19 was obtained from the Washington State University Creamery.

\section{Cheese Manufacture}

The milk was standardized before pasteurization $\left(73^{\circ} \mathrm{C}, 17 \mathrm{~s}\right)$ to ensure residual lactose in fresh cheese, and similar compositions of milk were used for cheese manufacture. The protein/fat ratio (0.84) and lactose concentration $(5.2 \% \mathrm{wt} / \mathrm{vol})$ were standardized by adding cream (Vitamilk Dairy Inc., Seattle, WA) and Dlactose (Sigma Chemical Co., St. Louis, MO). Cheeses were manufactured in triplicate with each replicate made from 90.8-kg of milk. Starter culture of Lactococcus lactis ssp. cremoris \#355M (Gist-Brocades, Millville, UT) was grown to a cell density of $10^{8} \mathrm{cfu} / \mathrm{ml}$ in sterilized skim milk then inoculated into the standardized milk at a rate of $1 \%(\mathrm{wt} / \mathrm{wt})$ at $31^{\circ} \mathrm{C}$. Lactobacillus curvatus \#1 or \#11 or L. helveticus WSU19 were grown to cell densities of $10^{8} \mathrm{cfu} / \mathrm{ml}$ in MRS broth (Becton Dickinson and Co., Sparks, MD) and enough of these adjunct cultures were added to milk to achieve initial populations of $10^{3} \mathrm{cfu} / \mathrm{ml}$ to mimic the low initial NSLAB typically found in cheese. Control cheeses were made without adding an adjunct culture. Double-strength coagulator (Chy-Max, Chr. Hansen Laboratories, Milwaukee, WI), diluted 1:40 with tap water was used to assist coagulation of the milk. At the time of cutting with 6 -mm cutter grid cheese knives, TA and $\mathrm{pH}$ were $0.13 \%$ and 6.76 , respectively. Curds were cooked by raising temperature from 31 to $38^{\circ} \mathrm{C}$ at the rate of $1^{\circ} \mathrm{C}$ every 5 min over a 30 -min period. Curds and whey were stirred at $38^{\circ} \mathrm{C}$ for 45 min before draining, at TA of $0.12 \%$, and cheddaring.

When the TA (as percentage lactic acid) of the whey reached $0.35 \%$, the loaves were milled and curds were salted $(0.3 \% \mathrm{wt} / \mathrm{wt}$ of milk). After overnight pressing at $2.8 \times 10^{5}-\mathrm{Pa}$, cheeses were cut into 150 -g pieces and vacuum packaged in $15 \times 20 \mathrm{~cm}$ of 3 -mil high barrier Nylon/EVOH/PE vacuum pouches (Koch Supplies Inc., Kansas City, MO). Finished cheeses were then aged at either 4 or $13^{\circ} \mathrm{C}$ (approximately 30 pieces per treatment). The $13^{\circ} \mathrm{C}$ temperature was selected since it is a temperature used for accelerated ripening of Cheddar 
cheese (Law et al., 1979). After $28 \mathrm{~d}$, half of the cheeses from 4 and $13^{\circ} \mathrm{C}$ were transferred to 13 and $4^{\circ} \mathrm{C}$, respectively, for the remainder of aging. The four treatments will subsequently be referred to as $4^{\circ} \mathrm{C}$ (aged at $4^{\circ} \mathrm{C}$ ), 4 to $13^{\circ} \mathrm{C}$ (aged at $4^{\circ} \mathrm{C}$ for $28 \mathrm{~d}$ and then transferred to $13^{\circ} \mathrm{C}$ ), 13 to $4^{\circ} \mathrm{C}$ (aged at $13^{\circ} \mathrm{C}$ for $28 \mathrm{~d}$ and then transferred to $4^{\circ} \mathrm{C}$ ), and $13^{\circ} \mathrm{C}$ (aged at $13^{\circ} \mathrm{C}$ ). Cheeses were sampled at d 0 (end of cheese manufacture), 1 (after overnight pressing), 5, 28, 35, 49, and $70 \mathrm{~d}$ post cheese manufacture.

\section{Cheese Sampling}

Total bacterial populations were determined by the pour plate method (Marshall, 1992) using 2\% (wt/vol) sodium citrate $\left(45^{\circ} \mathrm{C}\right), 0.1 \%$ (wt/vol) peptone, and MRS agar followed by anaerobic incubation (BBL GasPak 150 systems and anaerobic system envelopes with palladium catalyst, Becton Dickinson and Co., Sparks, MD) at $30^{\circ} \mathrm{C}$ for $48 \mathrm{~h}$. Concentrations of lactose, $\mathrm{D}(-)$ lactate, and L(+)-lactate in cheeses were measured using the lactose/D-galactose and D-lactic acid/L-lactic acid test kits, according to detailed inserts (Boehringer Mannheim, Indianapolis, IN). Absorbances were measured using an Ultraspec 4000 spectrophotometer (Pharmacia Biotech Inc., San Francisco, CA). Data obtained were analyzed with LSD using SAS Proc GLM (SAS Institute, 1989).

Each 150-g cheese was monitored daily for formation of white crystals on the surface of the cheese. Crystal formation was assessed by eye, since visible crystals are unappealing to consumers. Crystal identity was confirmed after initial observation. When crystals were observed by visual inspection, crystals were collected, washed with ether twice to remove adhering fat, then placed in a desiccator overnight. Crystal samples were then ground to fine powders using mortar and pestle and examined for the X-ray diffraction patterns using a Siemens D 500 diffractometer (Siemens Co., New York, $\mathrm{NY}$ ). Copper $\mathrm{k} \alpha$ radiation at $30 \mathrm{~mA}$ and an accelerating voltage of $35 \mathrm{kV}$ was used. Diffraction patterns were collected from 5 to 60 degrees at a scan rate of $2 \theta / \mathrm{min}$ with a step size of 0.05 and counting time of $2 \mathrm{~s}$. The patterns were then compared with lists of known materials to confirm crystal identity.

\section{RESULTS AND DISCUSSION}

\section{Observations of Crystal Development}

Crystals were not visually observed on the control cheeses or cheeses containing L. helveticus WSU19 throughout the 70-d aging period, regardless of temperature treatment. On the other hand, crystals composed of calcium lactate hydrate started to develop on cheeses containing L. curvatus \#1 or \#11 at d 42 and 35, respectively. The development and distribution of crystals were similar on cheeses manufactured with $L$. curvatus \#1 or \#11 handled with the same temperature treatment. Specifically, at d 70, the distribution and density of crystals on cheeses made with $L$. curvatus \#1 or \#11 stored at $4^{\circ} \mathrm{C}$ were similar; the density of crystals on cheeses made with L. curvatus \#1 or \#11 stored at 4 to $13^{\circ} \mathrm{C}$ were similar; the density of crystals on cheeses made with $L$. curvatus $\# 1$ or $\# 11$ stored at $13^{\circ} \mathrm{C}$ were similar; the density of crystals on cheeses made with L. curvatus \#1 or \#11 stored at 13 to $4^{\circ} \mathrm{C}$ were similar. However, time of appearance and density of CLC differed on cheeses with different temperature treatments. For instance, in cheeses manufactured with $L$. curvatus \#11, CLC was first observed at d 35 on the cheeses with storage treatment 13 to $4^{\circ} \mathrm{C}$; CLC was observed on cheeses stored at $4^{\circ} \mathrm{C}$ on $\mathrm{d} 42$; CLC was observed on cheeses with storage treatment 4 to $13^{\circ} \mathrm{C}$ and $13^{\circ} \mathrm{C}$ on $\mathrm{d} 52$. Crystals consistently developed first on cheeses aged under treatment 13 to $4^{\circ} \mathrm{C}$. The extent of CLC on cheeses containing L. curvatus \#1 or \#11 increased throughout $70 \mathrm{~d}$ aging. At d 70, CLC was heaviest on the cheeses with storage treatment 13 to $4^{\circ} \mathrm{C}$, followed by cheeses stored at either 4 or $13^{\circ} \mathrm{C}$, and lightest on the cheeses with storage treatment 4 to $13^{\circ} \mathrm{C}$. In all cases, visually observed crystals were evenly distributed on cheese surfaces and throughout the cheese matrix.

Because crystals initially appeared at different times on the same cheeses aged at different temperatures, aging temperature affected CLC. The results can be explained by two phenomena. First, aging of cheese at the higher temperature promoted NSLAB growth and $\mathrm{D}(-)$-lactate production in cheeses (Turner and Thomas, 1980). Since previous research showed that ripening at $13^{\circ} \mathrm{C}$ resulted in a 50\% increase in the rate of ripening compared to $6^{\circ} \mathrm{C}$ (Law et al., 1979), it follows that $\mathrm{D}(-)$ lactate production in cheeses stored at $13^{\circ} \mathrm{C}$ would be more rapid than $\mathrm{D}(-)$-lactate production in cheeses stored at $4^{\circ} \mathrm{C}$. Second, the solubility of calcium lactate salts decreases as temperature decreases (Linke, 1958). Therefore, it is likely that higher metabolism of NSLAB at $13^{\circ} \mathrm{C}$ resulted in the formation of $\mathrm{D}(-)$-lactate, then CLC was initiated when cheeses were moved from 13 to $4^{\circ} \mathrm{C}$ at $\mathrm{d} 28$ due to the decrease in solubility at the lower temperature. Although D(-)-lactate accumulated to a higher level in cheeses aged at $13^{\circ} \mathrm{C}$ than at $4^{\circ} \mathrm{C}$, the lower solubility of calcium lactate at $4^{\circ} \mathrm{C}$ initiated earlier observance of crystals on cheeses aged at 13 to $4^{\circ} \mathrm{C}$ than at $13^{\circ} \mathrm{C}$. Thus, since solubility of $\mathrm{D}(-)$-lactate at $4^{\circ} \mathrm{C}$ is lower than at $13^{\circ} \mathrm{C}, \mathrm{CLC}$ occurred at an earlier date in cheeses where $\mathrm{D}(-)$-lactate had first formed to a greater extent (at $13^{\circ} \mathrm{C}$ ) then was cooled (to $4^{\circ} \mathrm{C}$ ), than 
in cheeses continuously stored at either 4 or $13^{\circ} \mathrm{C}$, or moved from 4 to $13^{\circ} \mathrm{C}$.

\section{Total Bacterial Populations}

Throughout aging, total bacterial populations in cheeses manufactured with $L$. helveticus WSU19 were similar to control cheeses, while the populations in cheeses manufactured with $L$. curvatus \#1 were similar to cheeses manufactured with $L$. curvatus \#11 (Figure 1). Similar initial total bacterial populations in cheeses indicate that the growth of starter bacteria in experimental cheeses was not depressed by the addition of $L$. helveticus WSU19 or L. curvatus \#1 or \#11. As cheeses were aged, total bacterial populations decreased, in agreement with Fox et al. (2000). All cheeses initially aged at $4{ }^{\circ} \mathrm{C}$ showed a decrease in total bacteria after d 28, regardless of the addition of an adjunct culture (Figure 1). However, for cheeses initially aged at $13^{\circ} \mathrm{C}$, bacterial populations in control cheeses and cheeses containing $L$. helveticus WSU19 responded differently than bacterial populations in cheeses containing L. curvatus \#1 or \#11 after d 28 (Figure 1). Total bacteria in cheeses containing $L$. curvatus \#1 or \#11 were higher $(P$ $<0.05$ ) than in control cheeses and cheeses containing $L$. helveticus WSU19. Moreover, beyond d 0, total bacteria count in control cheeses were always higher $(P<0.05)$ than in cheeses containing $L$. helveticus WSU19. The observance that total bacterial populations were higher $(P<0.05)$ in cheeses aged at $4^{\circ} \mathrm{C}$ than at $13^{\circ} \mathrm{C}$ at $\mathrm{d} 70$ is explained by the higher metabolism of bacteria at $13^{\circ} \mathrm{C}$ than at $4^{\circ} \mathrm{C}$. High metabolic rate results in an early approach of the stationary phase and death phase of bacteria (Turner and Thomas, 1980; White, 2000).

At the time CLC was visually observed on cheeses (after d 35), bacterial populations in cheeses containing L. curvatus \#1 or \#11 were approximately $10^{8} \mathrm{cfu} / \mathrm{g}$, regardless of storage temperature. Populations in control cheeses or those with $L$. helveticus WSU19 were approximately $10^{7} \mathrm{cfu} / \mathrm{g}$, only one log less than cheeses containing $L$. curvatus \#1 or \#11. Thus, total bacterial populations in cheeses alone do not determine CLC; types of NSLAB and metabolism of NSLAB contribute to CLC.

\section{Lactose, $\mathrm{D}(-)$-Lactate, and L(+)-Lactate Concentrations}

Throughout aging, lactose, D(-)-lactate, and L(+)-lactate concentrations in cheeses manufactured with $L$. helveticus WSU19 (Figure 3) were similar to levels measured in control cheeses (Figure 2), while the concentrations in cheeses manufactured with L. curvatus \#1(Figure 4) were similar to cheeses manufactured with $L$.
A)

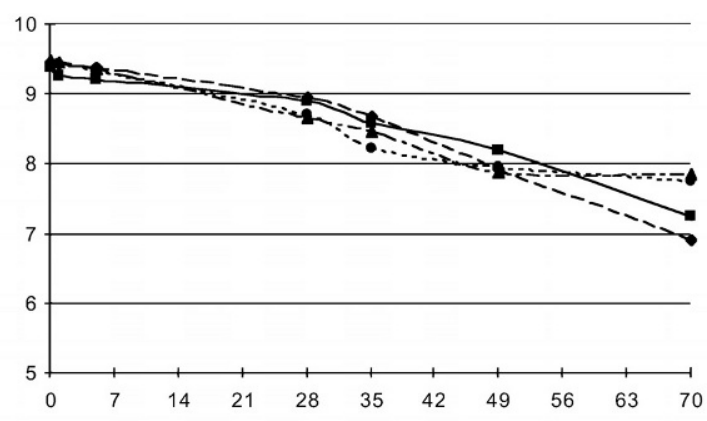

B)

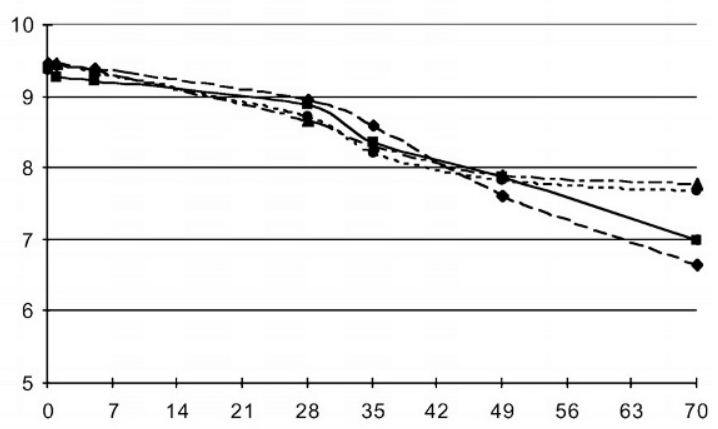

C)

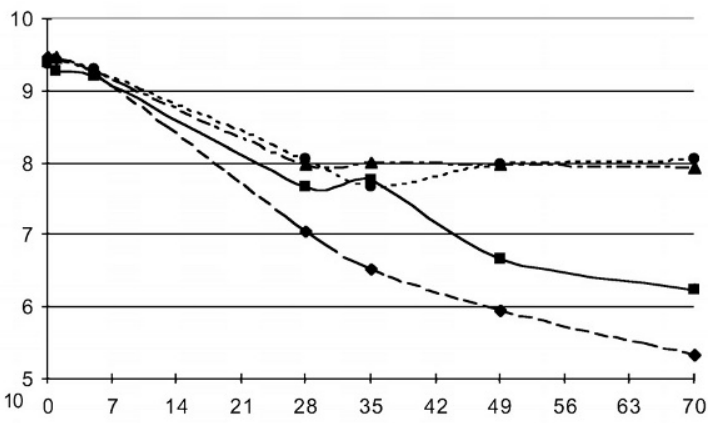

D)

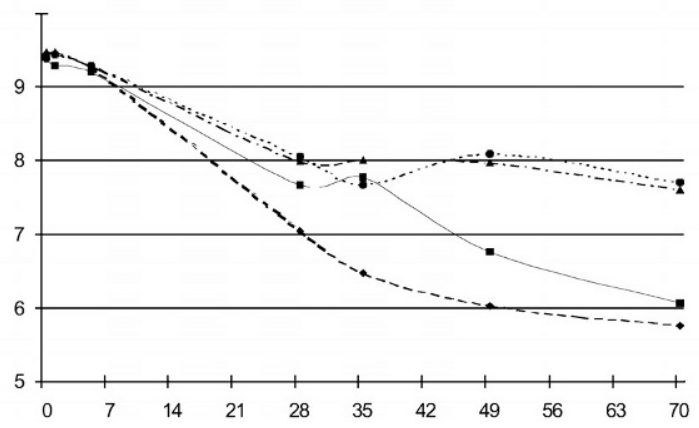

Figure 1. Total bacterial numbers in Cheddar cheese made with starter culture alone (ם), or with Lactobacillus helveticus WSU19

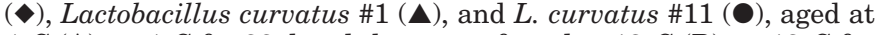
$4^{\circ} \mathrm{C} \mathrm{(A),} \mathrm{at} 4^{\circ} \mathrm{C}$ for $28 \mathrm{~d}$ and then transferred to $13^{\circ} \mathrm{C}(\mathrm{B})$, at $13^{\circ} \mathrm{C}$ for $28 \mathrm{~d}$ and then transferred to $4^{\circ} \mathrm{C}(\mathrm{C})$, and at $13^{\circ} \mathrm{C}(\mathrm{D})$. Data presented are the means of two measurements on triplicate cheeses manufactured.

curvatus \#11 (Figure 5). Lactose concentrations were higher in cheeses aged at 4 than at $13^{\circ} \mathrm{C}$, showing that lactose depletion was significantly more rapid at the 
A)

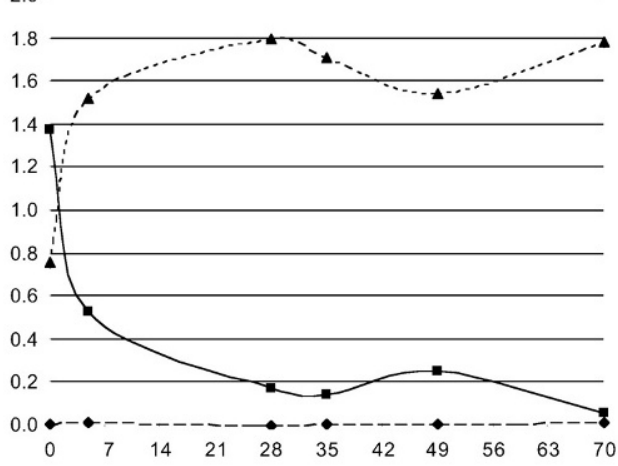

B)

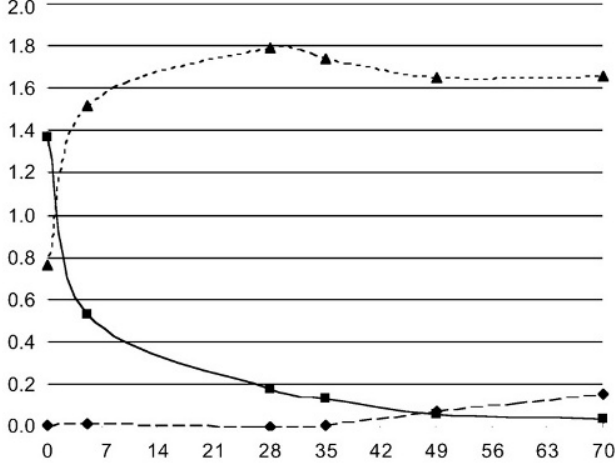

C)

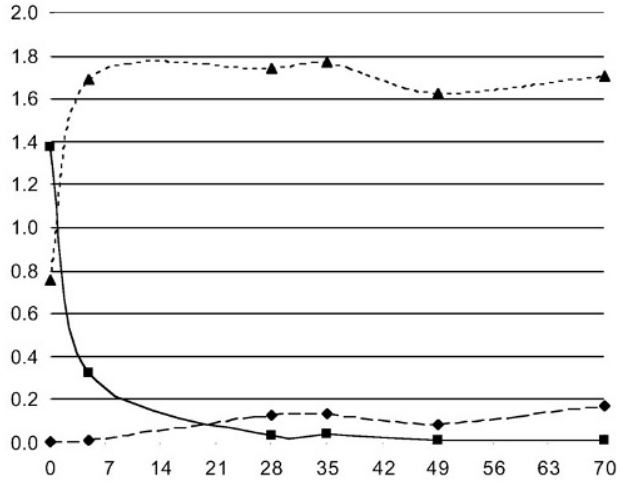

D)

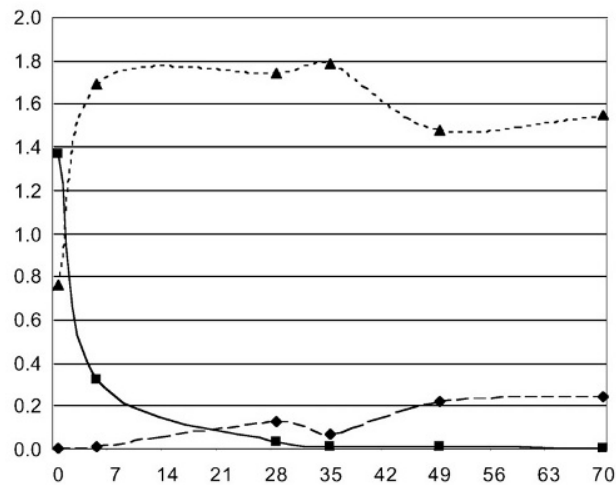

Figure 2. Lactose [ $\mathbf{\square}], \mathrm{D}(-)$-lactate $[\boldsymbol{\nabla}$, and L(+)-lactate [ $\mathbf{\Delta}]$ concentrations in control Cheddar cheeses that were aged at $4^{\circ} \mathrm{C}(\mathrm{A})$, aged at $4^{\circ} \mathrm{C}$ for $28 \mathrm{~d}$ and then transferred to $13^{\circ} \mathrm{C}(\mathrm{B})$, aged at $13^{\circ} \mathrm{C}$ for 28 $\mathrm{d}$ and then transferred to $4^{\circ} \mathrm{C}(\mathrm{C})$, and aged at $13^{\circ} \mathrm{C}(\mathrm{D})$. Data presented are the means of duplicate determinations on triplicate cheeses manufactured.
A)

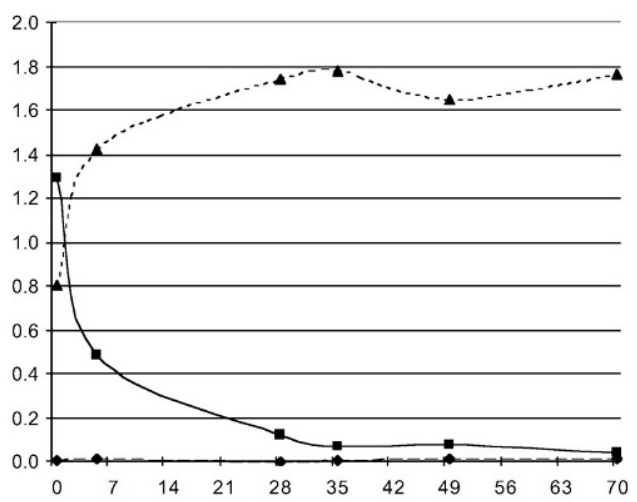

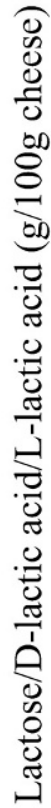

B)

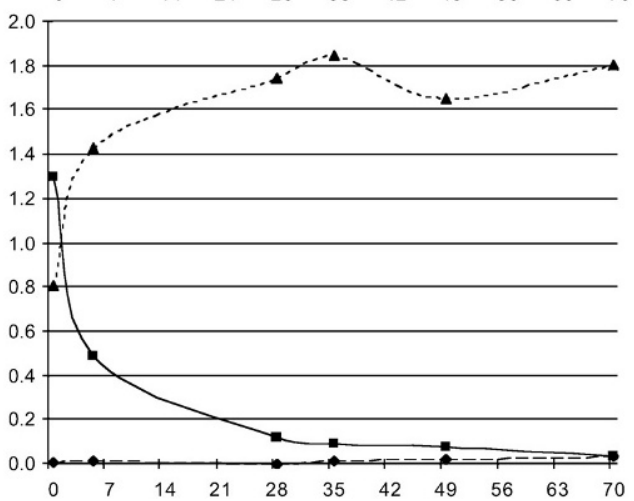

C)

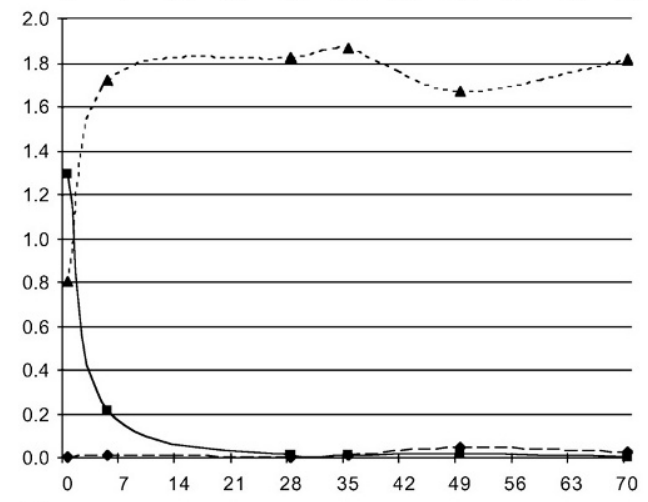

D)

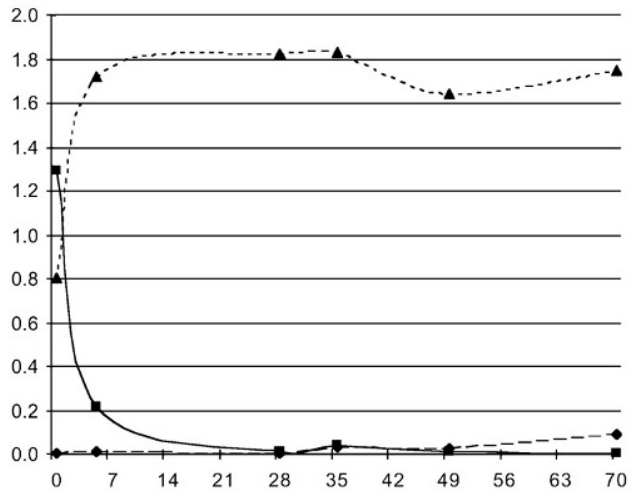

Figure 3. Lactose [ $\mathbf{\square}], \mathrm{D}(-)$-lactate $[\boldsymbol{\nabla}$, and L(+)-lactate [ $\mathbf{\Delta}]$ concentrations in Cheddar cheeses manufactured with Lactobacillus helveticus WSU19 that were aged at $4^{\circ} \mathrm{C}(\mathrm{A})$, aged at $4^{\circ} \mathrm{C}$ for $28 \mathrm{~d}$ and then transferred to $13^{\circ} \mathrm{C}(\mathrm{B})$, aged at $13^{\circ} \mathrm{C}$ for $28 \mathrm{~d}$ and then transferred to $4^{\circ} \mathrm{C}(\mathrm{C})$, and aged at $13^{\circ} \mathrm{C}(\mathrm{D})$. Data presented are the means of duplicate determinations on triplicate cheeses manufactured. 

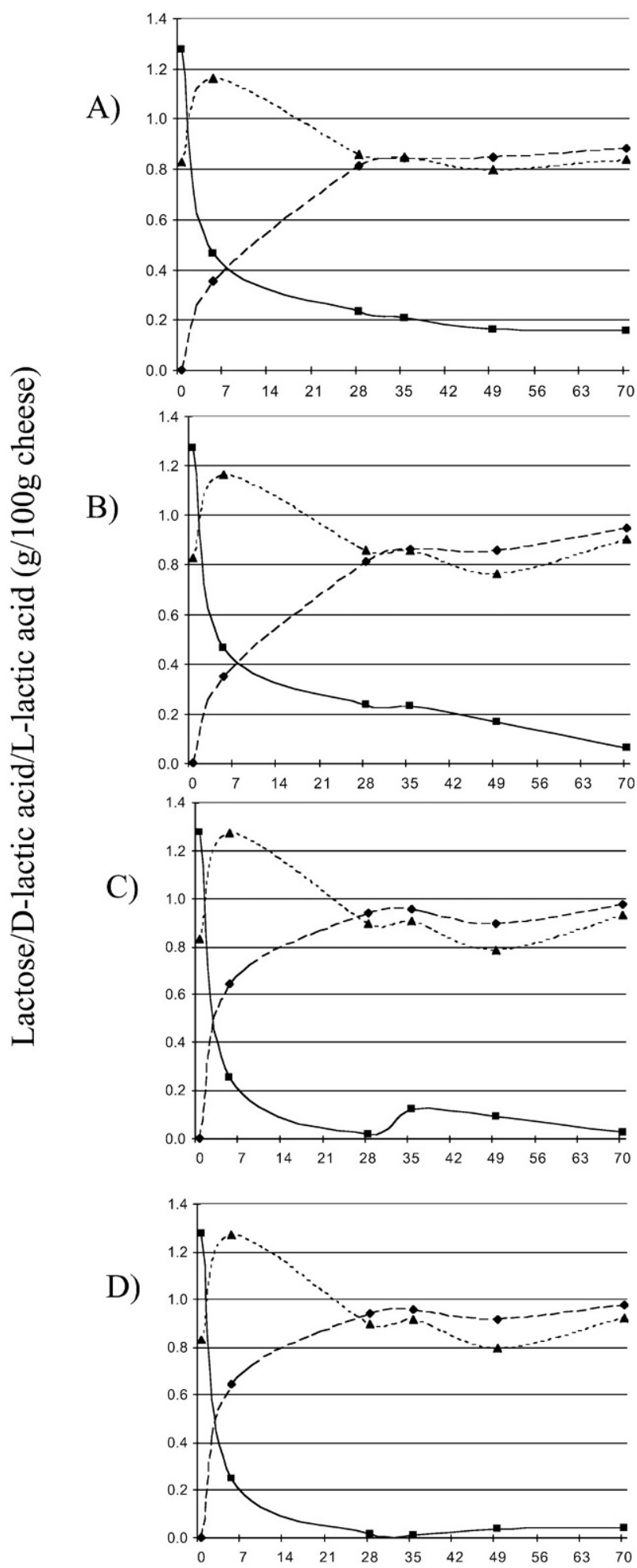

Figure 4. Lactose $[\mathbf{\square}], \mathrm{D}(-)$-lactate $[\bullet]$, and L(+)-lactate [ $\mathbf{A}]$ concentrations in control Cheddar cheeses manufactured with Lactobacillus curvatus \#1 that were aged at $4^{\circ} \mathrm{C}(\mathrm{A})$, aged at $4^{\circ} \mathrm{C}$ for $28 \mathrm{~d}$ and then transferred to $13^{\circ} \mathrm{C}(\mathrm{B})$, aged at $13^{\circ} \mathrm{C}$ for $28 \mathrm{~d}$ and then transferred to $4^{\circ} \mathrm{C}(\mathrm{C})$, and aged at $13^{\circ} \mathrm{C}(\mathrm{D})$. Data presented are the means of duplicate determinations on triplicate cheeses manufactured.
A)

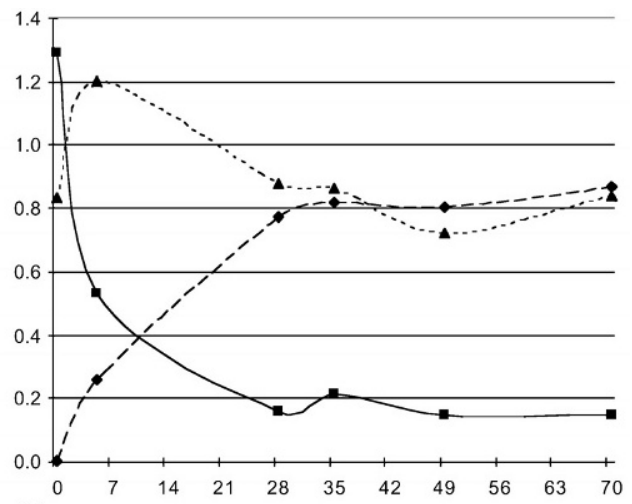

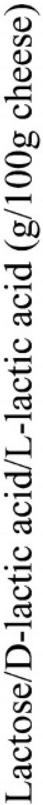

B)

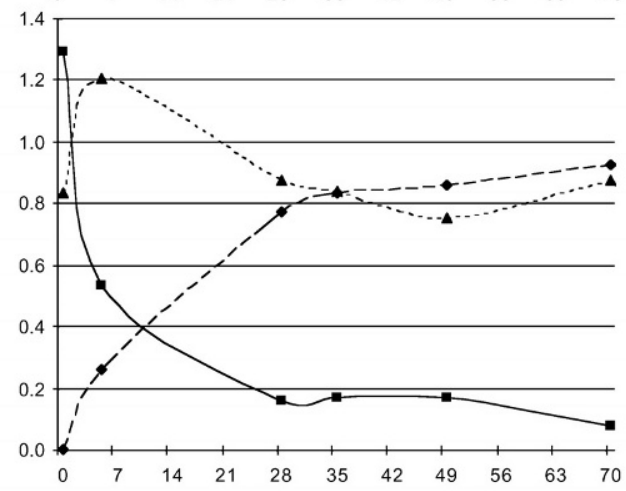

C)

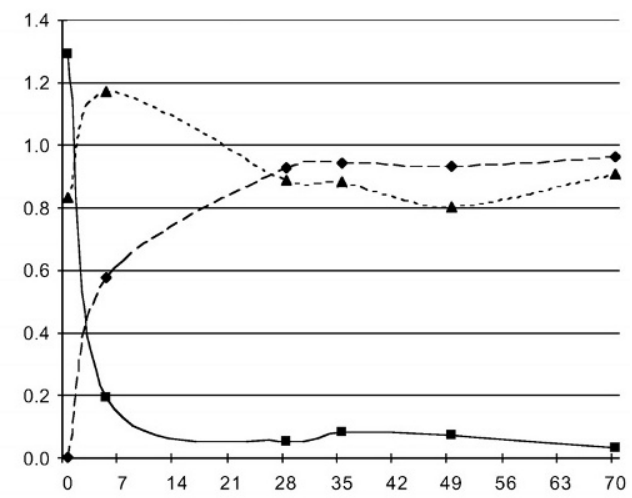

D)

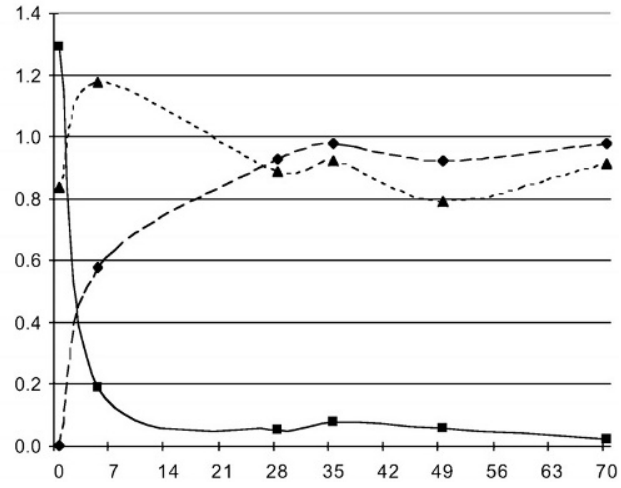

Figure 5. Lactose [ $\mathbf{\square}], \mathrm{D}(-)$-lactate [ $\boldsymbol{\bullet}$, and L (+)-lactate [ $\mathbf{\Delta}]$ concentrations in control Cheddar cheeses manufactured with Lactobacillus curvatus \#11 that were aged at $4^{\circ} \mathrm{C}(\mathrm{A})$, aged at $4^{\circ} \mathrm{C}$ for $28 \mathrm{~d}$ and then transferred to $13^{\circ} \mathrm{C}(\mathrm{B})$, aged at $13^{\circ} \mathrm{C}$ for $28 \mathrm{~d}$ and then transferred to $4^{\circ} \mathrm{C}(\mathrm{C})$, and aged at $13^{\circ} \mathrm{C}$ (D). Data presented are the means of duplicate determinations on triplicate cheeses manufactured. 
higher aging temperature $(P<0.05)$. This agrees with Turner and Thomas (1980) who found that the growth rate of nonstarter microorganisms and the rate of lactose utilization increased when the initial storage temperature was raised. The higher rate of lactose fermentation by lactic acid bacteria that occurred at $13^{\circ} \mathrm{C}$, corresponds to the lower total bacteria counts in cheeses aged at $13^{\circ} \mathrm{C}$ than at $4^{\circ} \mathrm{C}$ found in this research (Figure 1 ). The addition of adjunct cultures L. curvatus \#1 or \#11 significantly slowed $(P<0.05)$ lactose depletion in cheeses (Figures 4 and 5). Lactose concentrations in cheeses containing $L$. curvatus \#1 or \#11 were higher ( $P$ $<0.05$ ) than in cheeses containing $L$. helveticus WSU19 between days 35 and 70, showing that higher lactose fermentation occurred in cheeses containing $L$. helveticus WSU19 (Figure 3). The higher rate of lactose utilization by L. helveticus WSU19 corresponds to the higher metabolism and death rate shown in Figure 1.

Lactobacillus helveticus WSU19, L. curvatus \#1, and L. curvatus \#11 are all capable of fermenting lactose and forming lactate. However, initial concentrations of total lactate $[\mathrm{D}(-)$-lactate plus $\mathrm{L}(+)$-lactate] in all cheeses manufactured for this study were similar, suggesting the initial accumulation of lactate in cheeses was not affected by the addition of $L$. helveticus WSU19, L. curvatus \#1, or L. curvatus \#11. Initial lactate measured in all cheeses was only in the $\mathrm{L}(+)$ isomer (Figures 2 to 5 ).

Initial lactate concentration in all cheeses was similar, but after $\mathrm{d} 0$, the concentration of lactate was higher $(P<0.05)$ at $13^{\circ} \mathrm{C}$ than at $4^{\circ} \mathrm{C}$. Lactate in control cheeses and cheeses containing $L$. helveticus WSU19 remained predominately in the $\mathrm{L}(+)$ isomer during the $70 \mathrm{~d}$ of aging (Figures 2 and 3). However, the concentration of $\mathrm{L}(+)$-lactate in cheeses containing L. curvatus \#1 or \#11 decreased significantly $(P<0.05)$ (Figures 4 and 5$)$ to levels significantly lower than in cheeses containing L. helveticus WSU19. The decrease in L(+)-lactate in cheeses containing $L$. curvatus \#1 and \#11 was balanced by a significant $(P<0.05)$ increase in $\mathrm{D}(-)$-lactate (Figures 4 and 5). Because starter bacteria produce only $\mathrm{L}(+)$-lactate from the fermentation of lactose, the accumulation of $\mathrm{D}(-)$-lactate in cheeses containing $L$. curvatus \#1 or \#11 can be attributed to the metabolism of $L$. curvatus \#1 or \#11, or other secondary NSLAB.

The decrease in $\mathrm{L}(+)$-lactate concentration in cheese with $L$. curvatus \#1 or \#11 was due to the racemization of lactate, rather than the fermentation of lactate to acetate (Fox et al., 2000). The following observations support this hypothesis. The decrease in lactose concentration between $\mathrm{d} 5$ and 28 in cheese containing $L$. curvatus \#1 or \#11 aged at $13^{\circ} \mathrm{C}$ was 0.23 and $0.13 \mathrm{~g} /$ $100 \mathrm{~g}$, respectively. If $\mathrm{D}(-)$-lactate was the only isomer of lactate produced from lactose during this period, the increase in $\mathrm{D}(-)$-lactate concentration should be 0.25 and $0.14 \mathrm{~g} / 100 \mathrm{~g}$, respectively, in cheese containing $L$. curvatus \#1 and \#11. (The increase in D-lactate concentration in cheeses containing $L$. curvatus \#1 and \#11 should be 0.25 and 0.14 , rather than 0.23 and $0.13 \mathrm{~g} /$ $100 \mathrm{~g}$, due to the difference in molecular weight of lactose and lactate). However, the increase in $\mathrm{D}(-)$-lactate concentration between $\mathrm{d} 5$ and 28 was 0.30 and $0.35 \mathrm{~g} /$ $100 \mathrm{~g}$ in cheese containing L. curvatus \#1 and \#11, respectively. The $\mathrm{D}(-)$-lactate production in cheese containing L. curvatus \#1 and \#11 during this period was greater than could be accounted for from the fermentation of lactose alone. Moreover, as D(-)-lactate concentration increased, there was a decline in $\mathrm{L}(+)$-lactate concentration. The decrease in $\mathrm{L}(+)$-lactate concentration in cheese containing $L$. curvatus \#1 or \#11 during d 5 and 28 was 0.38 and $0.29 \mathrm{~g} / 100 \mathrm{~g}$, respectively. The simultaneous increase in $\mathrm{D}(-)$-lactate concentration and decrease in $\mathrm{L}(+)$-lactate concentration in cheese suggests that racemization of lactate took place and that the growth of $L$. curvatus contributed to the racemization of lactate, which resulted in CLC.

Johnson et al. (1990b) reported that calcium lactate crystals were observed on cheeses with approximately $25 \%$ of the total lactate in the $\mathrm{D}(-)$ isomer, and calcium lactate crystals were never observed on cheeses with less than $20 \%$ of the lactate in the $\mathrm{D}(-)$ isomer (Johnson et al., 1990b). In the present study, the percentages of $\mathrm{D}(-)$-lactate in total lactate (D\%) in control cheeses and cheeses containing $L$. helveticus WSU19 was always lower than $15 \%$ throughout the aging period (Figure 6) and crystals were not observed. The $\mathrm{D} \%$ did not increase in control cheeses and cheeses containing $L$. helveticus WSU19 stored continuously at $4^{\circ} \mathrm{C}$. In contrast, D\% increased $(P<0.05)$ in all cheeses aged at $13^{\circ} \mathrm{C}$, regardless of when the $13^{\circ} \mathrm{C}$ treatment took place. These findings highlight the importance of carefully considering the potential disadvantage to elevated aging temperature, particularly if racemase-positive NSLAB exist in the cheese.

After $28 \mathrm{~d}$ of cheese manufacture, roughly 1:1 ratio of D/L-lactate was measured in cheeses containing $L$. curvatus \#1 or \#11, and the concentration of D/L-lactate remained at about the same level throughout $70 \mathrm{~d}$ of cheese aging (Figure 6). When cheeses were aged at $4^{\circ} \mathrm{C}, \mathrm{D} \%$ achieved $25 \%$ between 7 and $14 \mathrm{~d}$ after manufacture. When aged at $13^{\circ} \mathrm{C}, \mathrm{D} \%$ achieved $25 \%$ within 7 $\mathrm{d}$ after manufacture. Although those cheeses developed greater than $25 \%$ of the total lactate in the $\mathrm{D}(-)$ isomer shortly after cheesemaking, CLC was not observed until d 28 or 35 , when greater than $50 \%$ of the total lactate in the $\mathrm{D}(-)$ isomer was measured. This does not necessarily mean that greater than $50 \% \mathrm{D} \%$ is required for CLC to be observed. It is possible that if $\mathrm{D}(-)$-lactate production had stopped at $25 \% \mathrm{D} \%$, CLC could have occurred either 

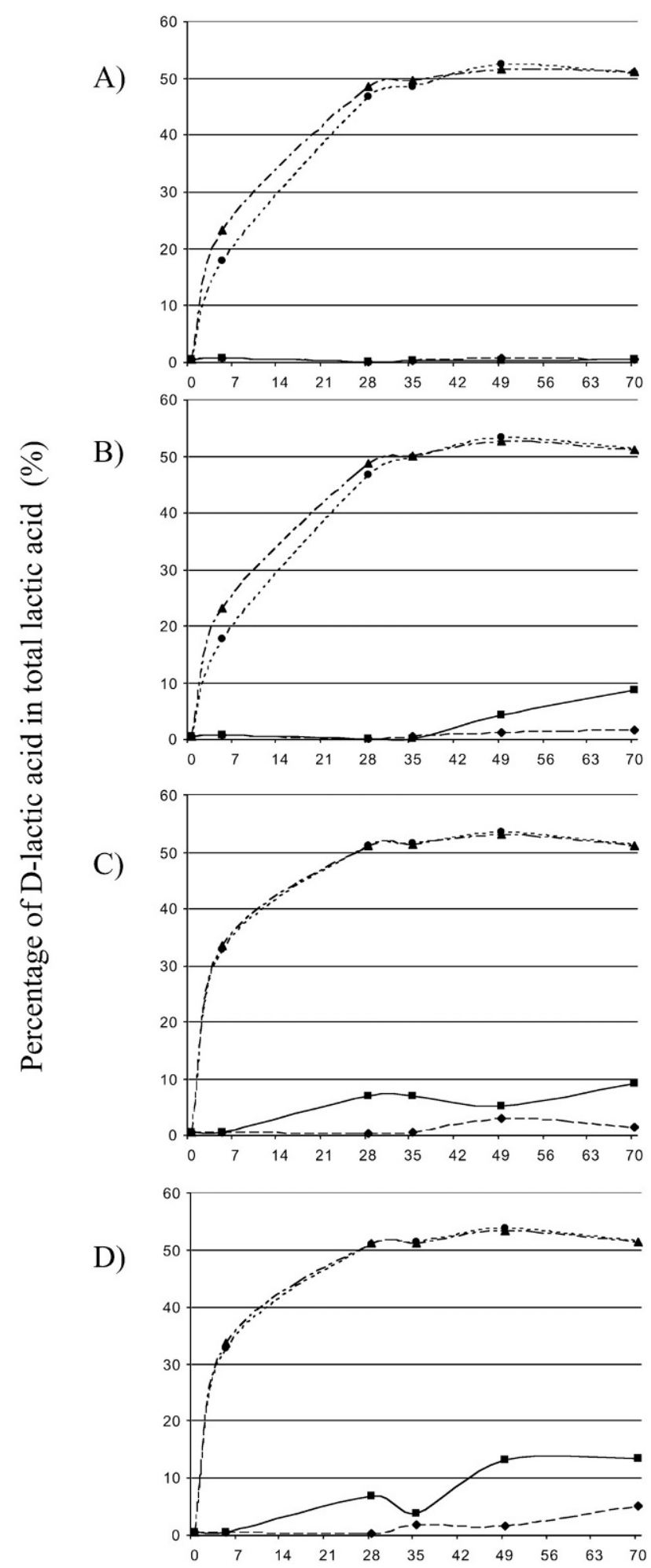

Figure 6. D-Lactic acid as a percentage of total lactic acid in cheeses made with starter culture alone (ם) or with Lactobacillus helveticus WSU19 (\$), Lactobacillus curvatus \#1 (\$), or L. curvatus \#11 (-) that were aged at $4^{\circ} \mathrm{C}(\mathrm{A})$, aged at $4^{\circ} \mathrm{C}$ for $28 \mathrm{~d}$ and then transferred to $13^{\circ} \mathrm{C}(\mathrm{B})$, aged at $13^{\circ} \mathrm{C}$ for $28 \mathrm{~d}$, and then transferred to $4^{\circ} \mathrm{C}(\mathrm{C})$ and aged at $13^{\circ} \mathrm{C}(\mathrm{D})$. when a package was opened (before d 35), or later in the storage period. Since no data points were collected between $\mathrm{d} 6$ and 27, it is not clear how much $\mathrm{D}(-)$ developed each day during that time period or whether $50 \%$ $\mathrm{D} \%$ was a critical point for CLC. Seeding for CLC may require time for initiation. The differences in $\mathrm{D} \%$ at CLC observation in this study compared to previous research (Johnson et al., 1990b) might be explained by the differences in aging temperature used. While Johnson et al. (1990b) aged cheese at $3^{\circ} \mathrm{C}, 4^{\circ} \mathrm{C}$ was used for the present study. The lower solubility of calcium lactate at a lower temperature may explain why CLC appeared at around $20 \% \mathrm{D} \%$ on the cheeses that the previous researchers manufactured. Additional research is necessary to confirm whether a critical $\mathrm{D} \%$ or timing plays a larger role in CLC.

\section{CONCLUSIONS}

Aging temperature and formation of $\mathrm{D}(-)$-lactate affect CLC in maturing Cheddar cheese. Cheddar cheese manufactured with $L$. curvatus spp. rapidly developed a mixture of $\mathrm{D} / \mathrm{L}-$ lactate during aging. Elevated aging temperature increased the rate of $\mathrm{D}(-)$-lactate racemization by $L$. curvatus spp., and CLC was initiated when cheeses were moved to a lower temperature, due to the lower solubility of calcium lactate at low temperatures. Crystals were not observed on control cheeses and cheeses manufactured with $L$. helveticus WSU19 during the 70-d aging period because only less than $15 \%$ of the total lactate was present in the $\mathrm{D}(-)$ isomer. Aging cheese at elevated temperatures that accelerate maturation may potentially promote secondary NSLAB growth, $\mathrm{D}(-)$-lactate formation, and CLC.

\section{ACKNOWLEDGMENTS}

This project was supported by grants from the Washington State Dairy Products Commission. The authors would like to express their appreciation to Doug Anker, Nial Yager, Shih-Yu Lin, Anthony Blake, Heidi Warner, Anchalee Sirichote, and Barry Swanson and Joe Powers for assistance and discussion.

\section{REFERENCES}

Blake, A. 2000. Cheese-milk lactose concentration, lactic acid production, and calcium lactate crystal formation in Cheddar cheese. M.S. Thesis, Washington State University, Pullman, WA.

Dybing, S. T., J. A. Wiegand, S. A. Brudvig, E. A. Huang, and R. C. Chandan. 1988. Effect of processing variables on the formation of calcium lactate crystals on Cheddar cheese. J. Dairy Sci. 71:1701-1710.

Fox, P. F., T. P. Guinee, T. M. Cogan, and P. L. H. McSweeney. 2000. Fundamentals of Cheese Science. Aspen Publ., Gaithersburg, MD.

International Dairy Foods Association. 2001. Cheese Facts. 2001 ed. International Dairy Foods Association, Washington, DC. 
Johnson, M. E., B. A. Riesterer, C. Chen, B. Tricomi, and N. F. Olson. 1990a. Effect of packaging and storage conditions on calcium lactate crystallization on the surface of Cheddar cheese. J. Dairy Sci. 73:3033-3041.

Johnson, M. E., B. A. Riesterer, and N. F. Olson. 1990b. Influence of nonstarter bacteria on calcium lactate crystallization on the surface of Cheddar cheese. J. Dairy Sci. 73:1145-1149.

Khalid, N. M., and E. H. Marth. 1990. Lactobacilli-their enzymes and role in ripening and spoilage of cheese: A review. J. Dairy Sci. 73:2669-2684.

Law, B., Z. Kosking, and H. Chapman. 1979. The effect of some manufacturing conditions on the development of flavour in Cheddar cheese. J. Soc. Dairy Technol. 32:87-90.

Linke, W. F., ed. 1958. Solubilities of Inorganic and Metal Organic Compounds. 4th ed. Am. Chem. Soc., Washington, DC.

Marshall, T. R., ed. 1992. Standard Methods for the Examination of Dairy Products. 15th ed. Am. Publ. Health Assoc., Inc., Washington, DC.

McDowall, F. H., and A. K. R. McDowell. 1939. The white particles in mature Cheddar cheese. J. Dairy Res. 10:118-119.

Pearce, K. N., L. K. Creamer, and J. Gilles. 1973. Calcium lactate deposits on rindless Cheddar cheese. N.Z. J. Dairy Sci. Technol. $8: 3-7$.

Rengpipat, S., and E. A. Johnson. 1989. Characterization of a Lactobacillus strain producing white crystals on Cheddar cheese. Appl. Environ. Microbiol. 55:2579-2582.
SAS Institute. 1989. SAS/STAT User's Guide. Version 6. 4th ed. Vol. 1. SAS Institute Inc., Cary, NC.

Severn, D. J., M. E. Johnson, and N. F. Olson. 1986. Determination of lactic acid in Cheddar cheese and calcium lactate crystals. J. Dairy Sci. 69:2027-2030.

Shakeel-Ur-Rehman, J. M. Banks, P. L. H. McSweeney, and P. F. Fox. Effect of ripening temperature on the growth and significance of non-starter lactic acid bacteria in Cheddar cheese made from raw or pasteurized milk. Int. Dairy J. 10:45-53.

Somers, E. B., M. E. Johnson, and A. C. L. Wong. 2001. Biofilm formation and contamination of cheese by nonstarter lactic acid bacteria in the dairy environment. J. Dairy Sci. 8:1926-1937.

Thomas, T. D., and V. L. Crow. 1983. Mechanism of $\mathrm{D}(-)$-lactic acid formation in Cheddar cheese. N.Z. J. Dairy Sci. Technol. 18:131-141.

Turner, K. W., and T. D. Thomas. 1980. Lactose fermentation in Cheddar cheese and the effect of salt. N.Z. J. Dairy Sci. Technol. 15:265-276.

White, D. 2000. The Physiology and Biochemistry of Prokaryotes. 2nd ed. Oxford Univ. Press, New York, NY.

Williams, A. G., S. E. Withers, and J. M. Banks. 2000. Energy sources of non-starter lactic acid bacteria isolated from Cheddar cheese. Int. Dairy J. 10:17-23.

Zúñiga, M., I. Pardo, and S. Ferrer. 1993. An improved medium for distinguishing between homofermentative and heterofermentative lactic acid bacteria. Int. J. Food Microbiol. 18:37-42. 